International Journal of

Health, Medicine and

Nursing Practice

(IJHMNP)

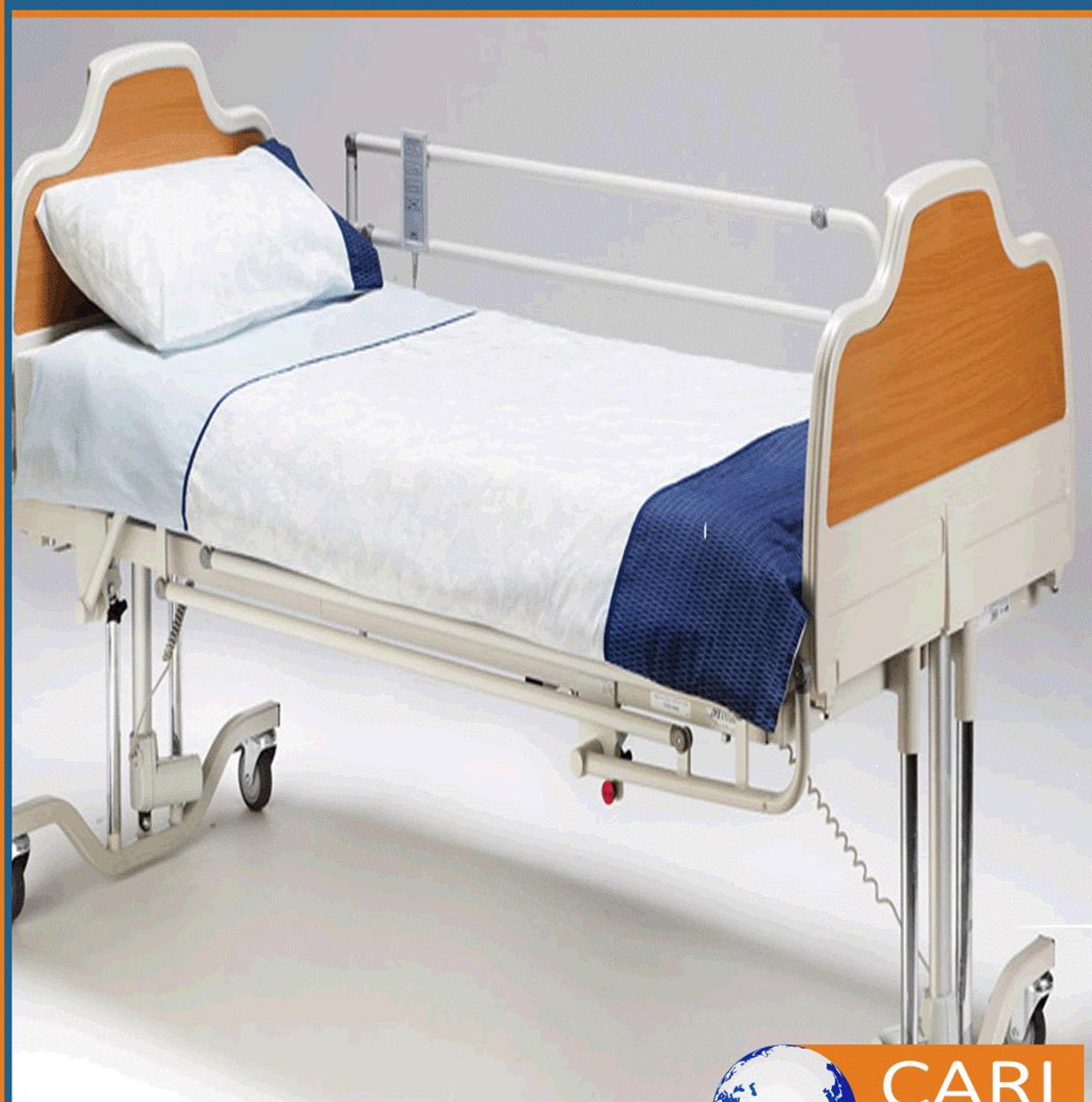




\title{
Microbial load of healthcare wastes in Aba Metropolis, Abia State
}

\author{
${ }^{1 *}$ Elendu, C. Onwuchekwa., ${ }^{2}$ Anaele, C. C., ${ }^{3}$ Emeonye, O. P., ${ }^{4}$ Felix C. J., ${ }^{5}$ Ikechukwu- \\ Okoroezi, J., ${ }^{6} \mathrm{Kanu}$, S. A. J., ${ }^{7}$ Ubaji, U. and ${ }^{8}$ Maduagwu Queen Chinyere \\ ${ }^{1,2}$ Department of Public Health, Abia State University Uturu, Abia State, Nigeria \\ ${ }^{3,5,6}$ Department of Nursing Sciences, Abia State University Uturu, Abia State, Nigeria \\ ${ }^{4}$ Ministry of Health, Abia State, Nigeria \\ ${ }^{7}$ Department of Nursing Sciences, Gregory University Uturu, Abia State, Nigeria \\ ${ }^{8}$ Department of Biology, Federal College of Education, Pankshin, Plateau State, Nigeria \\ *Corresponding author's E-mail address: uzochukwugods@gmail.com
}

\begin{abstract}
Introduction: Healthcare waste is the total waste both solid and liquid from healthcare establishment and laboratories. A hospital produces waste by giving their services to the patients. Purpose: This study examined the microbial load of waste from selected healthcare facilities in Aba metropolis, Abia State.

Methodology: Tenfold serial dilution was used for processing of all the samples. After the dilutions, exactly $0.5 \mathrm{ml}$ of each the sample was planted on the media using the spread plate method and evaluated using the standard microbiological techniques.

Results: The viable count (TVC) ranged from $1.0 \times 10^{3} \mathrm{cfu} / \mathrm{g}$ to $0.3 \times 10^{8} \mathrm{cfu} / \mathrm{g}$, coliform count (TCC) ranged from $0.4 \times 10^{2} \mathrm{cfu} / \mathrm{g}$ to $4.2 \times 10^{4} \mathrm{cfu} / \mathrm{g}$, staphylococcal count (TSC) ranged from $1.0 \times 10^{1} \mathrm{cfu} / \mathrm{g}$ to $1.4 \times 10^{2}$ and fungal counts ranged from $2.0 \times 10^{2} \mathrm{cfu} / \mathrm{g}$ to $0.8 \times 10^{3} \mathrm{cfu} / \mathrm{g}$ in the microbial count of various waste samples within the Aba metropolis, Abia State. The laboratory waste had the highest microbial counts, followed by the Out-patient department waste and the least was the pharmaceutical waste. The microorganisms isolated from the hospital wastes were Staphylococcus aureus, Pseudomonas aeruginosa, Escherichia coli, Aspergillus niger, A. Fumigatus, Candida albicans and among others.

Unique contribution to theory, practice and policy: This research has revealed that healthcare waste contained pathogens with high microbial load densities, suggesting that the hospital wastes may pose a major health and environmental threat, if not properly managed. The study recommends that, the government should ensure that there is a policy on hospital waste management in line with recommended international best practices, which should be monitored and enforced.
\end{abstract}

Key words: Microbial load, waste, organisms, healthcare 
International Journal of Health, Medicine and Nursing Practice ISSN 2710-1150 (Online)

Vol. 3, Issue No. 1, pp 17 - 23, 2021

$\underline{\text { www.carijournals.org }}$

\subsection{INTRODUCTION}

Healthcare waste also termed biomedical waste contains infectious, contaminated and hazardous waste such as discarded sharps, non-sharps, blood, body parts, toxic chemicals, pharmaceuticals, medical devices and radioactive substances. If not managed properly, it carries a substantial risk to the hospital staff, the patients, the community, public health and environment (Gibson et al., 2012; Ogbonna et al., 2011). The World Health Organization asserted that the impact of improper hospital waste disposal is felt the more in developing African countries including Nigeria this can be attributed to poor waste management by the health professionals and poor administration of public health system (WHO, 2014).

Hospital waste are referred to those solid and liquid wastes from health care establishment, research facilities, and laboratories, blood banks, nursing homes, mortuaries, autopsy centers. They could be classified into hazardous (such as infectious, pharmaceuticals, sharps, chemical, radioactive and heavy metal) and non-hazardous (such as paper, packaging, debris). It is the duty of hospitals and health care establishments to look after the public health and in the process of health care, waste is generated which usually include sharps, human tissues or body parts and other infectious materials (Patil \& Pokhrel, 2005).

However, the disposal of untreated health care wastes in landfills can lead to the contamination of drinking, surface, and ground waters if those landfills are not properly constructed. In addition, this disposal of waste in the landfill as part of waste management system is dangerous to the environment and human health (Ishaq et al., 2011). Healthcare waste management is one of the most ignored parts of the white-collar process in Nigeria. It was observed that consciousness regarding health hazards of health care waste among professional as well as general people is very low. With the rapid advancement of urbanization, the environment as well as the health conditions of city dwellers will be an unpleasant one. Due to complex components in healthcare waste, it creates greater environmental pollutions and make waste disposal and management more difficult (Kolpin et al., 2002). Hazardous waste must be packaged, transferred and disposed of properly to protect both people and the environment. To this end, this work examined the microbial load of healthcare wastes in Aba Metropolis, Abia State.

\subsection{METHODOLOGY}

\subsection{Description of Abia State}

Abia is a state in the southeastern part of Nigeria. The capital is Umuahia and the major commercial city is Aba, formerly a British colonial government outpost. The state was created in 1991 from part of Imo State and its citizens are predominantly Igbo people (9.5\% of population). It is one of the nine constituent states of the Niger Delta region. The name "Abia" is an abbreviation of four of the state's densely populated regions Aba, Bende, Isuikwuato, and Afikpo. It is one of the thirtysix (36) States that constitute the Federal Republic of Nigeria. Their traditional language is Igbo. English is widely spoken and serves as the official language in governance and business.

The geographical location of the capital city (Umuahia) was at the latitude of 5.526 and longitude $7.489^{\circ}$ N. Abia state has 17 Local Government Areas such as Aba North, Aba South, Arochukwu, 
International Journal of Health, Medicine and Nursing Practice ISSN 2710-1150 (Online)

Vol. 3, Issue No. 1, pp 17 - 23, 2021

$\underline{\text { www.carijournals.org }}$

Bende, Ikwuano, IsialaNgwa North, IsialaNgwa South, Isuikwuato, Obi Ngwa, Ohafia, OsisiomaNgwa, Ugwunagbo, Ukwa East, Ukwa West, Umuahia North, Umuahia South and UmuNneochi.

The people of Abia Stale have a rich cultural heritage, which is subsumed in matriarchy and Age Grade system. Rich works of art can be found in Abia state, which includes cultural artifacts like the weaving of high-quality warriors' cap (okpuagu), beads, wooden kola disc (okwa) mortar, pestle and a variety of sculptural works. The majority of people in Abia State live in concrete-built houses with zinc roofs. It is rather not uncommon to find some thatched houses in deep rural settlements. The occupations of the people include' farmers, traders, v/elders, carpenters, civil servants, transport workers etc.

Abia State, occupies about 5,834 square kilometers, is bounded on the north and northeast by the states of Anambra, Enugu, and Ebonyi. To the west of Abia is bounded Imo State, to the east and southeast are Cross River State and AkwaIbom State, and to the south is Rivers State. It is lowlying tropical rain forest with some oil-palm brush the southern portion that gets the heavy rainfall of about 2,400 millimeters per year between the months of April to October. The rest of the State is moderately high plain and wooded savanna.

\subsection{Enumeration of microbial counts}

Ten-fold serial dilutions were used for processing of all the samples. After the dilutions, exactly $0.5 \mathrm{ml}$ of each the sample was planted on the media using the spread plate method and incubated. On establishment of growth, each culture plate was examined closely for distinct colonies (Amusa et al., 2005; Ugbogu et al., 2015; Ekeleme et al., 2020). The colonies formed on the surfaces of the agar were counted with colony counter and was expressed as colony forming unit per $\mathrm{ml}(\mathrm{cfu} / \mathrm{g}$ ) for each of the total viable microorganisms, total coliform, faecal coliform and fungi.

\subsection{Bacterial Isolation and Identification}

All the samples were cultured in sterile Petri dish plates containing nutrient agar, Mannitol Salt Agar, EMB, blood agar, MacConkey agar, and Sabouroud dextrose agar (SDA). After incubation at $37^{\circ} \mathrm{C}$ for $24 \mathrm{hrs}$ and at room temperature for $2-7$ days for bacteria and fungi respectively, the plates were observed, carefully examined and distinct growths were sub-cultured on fresh medium for purity. The bacterial isolates were characterized and identified based on their motility, microscopic and colonial morphologies, Gram staining reaction, biochemical tests which include; catalase, methyl red, vogesproskauer (MR-VP), nitrate reduction test, starch hydrolysis, gelatin liquefaction test, indole, oxidase, urease, triple sugar iron agar (TSI) and sugar fermentation as described in medical laboratory manual for tropical countries with reference to the Bergey's manual of systemic bacteriology (Gerhardt et al., 1994; Krieg and Holt, 1994; Cheesebrough, 2005, Elendu et al., 2019). The fungi were identified on the basis of their cultural and microscopic characteristics and with reference to the methods described by Barnett et al. (2000). 
International Journal of Health, Medicine and Nursing Practice ISSN 2710-1150 (Online)

Vol. 3, Issue No. 1, pp 17 - 23, 2021

$\underline{\text { www.carijournals.org }}$

\subsection{FINDINGS AND PRESENTATION}

The microbial count of various waste samples within the Abia State University Teaching Hospital, Aba showed that the viable count (TVC) ranged from $1.5 \times 10^{3} \mathrm{cfu} / \mathrm{g}$ to $2.1 \times 10^{7} \mathrm{cfu} / \mathrm{g}$. The coliform count (TCC) ranged from $0.4 \times 10^{2} \mathrm{cfu} / \mathrm{g}$ to $4.2 \times 10^{4} \mathrm{cfu} / \mathrm{g}$, the staphylococcal count (TSC) ranged from $1.0 \times 10^{1} \mathrm{cfu} / \mathrm{g}$ to $1.4 \times 10^{2}$ and the fungal counts ranged from $2.0 \times 10^{2} \mathrm{cfu} / \mathrm{g}$ to $0.8 \times 10^{3} \mathrm{cfu} / \mathrm{g}$. However, the laboratory waste had the highest microbial counts, followed by the Out-patient department waste and the least was the pharmaceutical waste (Table 1).

Table 1: Microbial count of waste samples from Abia State University Teaching Hospital, Aba.

\begin{tabular}{lcccc}
\hline & \multicolumn{4}{c}{ COUNTS (CFU/g) } \\
\hline Samples & TVC & TCC & TSC & TFC \\
\hline A & $1.5 \times 10^{3}$ & $0.4 \times 10^{2}$ & $1.0 \times 10^{1}$ & $2.0 \times 10^{2}$ \\
B & $2.1 \times 10^{7}$ & $4.2 \times 10^{4}$ & $1.4 \times 10^{2}$ & $0.8 \times 10^{3}$ \\
C & $1.2 \times 10^{5}$ & $1.8 \times 10^{3}$ & $0.8 \times 10^{2}$ & $0.4 \times 10^{3}$ \\
D & $3.0 \times 10^{4}$ & $4.4 \times 10^{2}$ & $0.5 \times 10^{2}$ & $2.3 \times 10^{2}$ \\
\hline
\end{tabular}

$A=$ Pharmaceutical waste, $B=$ Laboratory waste, $C=$ Out-patient department waste, $D=, T V C$ = Total Viable Count, TCC = Total Coliform Count, TSC = Total Staphylococcal Count, $T F C=$ Total Fungal Count.

Considering the waste from General Hospital, Aba, it showed that waste from the laboratory had the highest microbial counts of $0.3 \times 10^{8} \mathrm{cfu} / \mathrm{g}$ for viable count, $0.2 \times 10^{5} \mathrm{cfu} / \mathrm{g}$ for coliform count, $2.1 \times 10^{2} \mathrm{cfu} / \mathrm{g}$ for staphylococcal count and $1.1 \times 10^{2} \mathrm{cfu} / \mathrm{g}$ for fungal count. The waste from pharmaceutical unit (A) had the least microbial counts in the range of $4.5 \times 10^{1} \mathrm{cfu} / \mathrm{g}$ (TCC) to $2.0 \times 10^{3} \mathrm{cfu} / \mathrm{g}$ (TVC) (Table 2).

Table 2: Microbial count of waste samples from General Hospital, Aba.

\begin{tabular}{lcccc}
\hline & \multicolumn{4}{c}{ COUNTS (CFU/g) } \\
\hline Samples & TVC & TCC & TSC & TFC \\
\hline A & $2.0 \times 10^{3}$ & $4.5 \times 10^{1}$ & $0.2 \times 10^{2}$ & $2.5 \times 10^{2}$ \\
B & $0.3 \times 10^{8}$ & $0.2 \times 10^{5}$ & $2.1 \times 10^{2}$ & $1.1 \times 10^{3}$ \\
C & $2.0 \times 10^{6}$ & $4.5 \times 10^{3}$ & $1.0 \times 10^{2}$ & $0.6 \times 10^{3}$ \\
D & $2.9 \times 10^{3}$ & $0.5 \times 10^{3}$ & $0.3 \times 10^{2}$ & $0.3 \times 10^{3}$ \\
\hline
\end{tabular}

$A=$ Pharmaceutical waste, $B=$ Laboratory waste, $C=$ Out-patient department waste, $D=, T V C$ $=$ Total Viable Count, $T C C=$ Total Coliform Count, $T S C=$ Total Staphylococcal Count, TFC = Total Fungal Count.

The waste samples from the Seventh-Day Adventist, Hospital, Aba followed the same trend. Sample B (laboratory waste) having the highest microbial counts, while the least was sample A (pharmaceutical waste). The pharmaceutical waste was mostly paper and containers which maintained dry surfaces, discouraging the growth of most microorganisms except for those with low water activity (Table 3 ). 
International Journal of Health, Medicine and Nursing Practice ISSN 2710-1150 (Online)

Vol. 3, Issue No. 1, pp 17 - 23, 2021

$\underline{\text { www.carijournals.org }}$

Table 3: Microbial count of waste samples from Seventh-Day Adventist Hospital, Aba.

\begin{tabular}{lcccc}
\hline \multicolumn{4}{c}{ COUNTS (CFU/g) } \\
\hline Samples & TVC & Samples & TVC & Samples \\
\hline A & $1.0 \times 10^{3}$ & $1.6 \times 10^{2}$ & $2.6 \times 10^{1}$ & $2.1 \times 10^{2}$ \\
B & $2.8 \times 10^{6}$ & $2.0 \times 10^{4}$ & $2.8 \times 10^{2}$ & $1.0 \times 10^{2}$ \\
C & $3.8 \times 10^{4}$ & $1.6 \times 10^{3}$ & $1.1 \times 10^{2}$ & $0.9 \times 10^{3}$ \\
D & $4.1 \times 10^{4}$ & $2.3 \times 10^{2}$ & $1.9 \times 10^{1}$ & $2.8 \times 10^{2}$ \\
\hline A= Pharmaceutical waste, B = Laboratory waste, C $=$ Out-patient department waste, D $=, T V C$ \\
= Total Viable Count, TCC = Total Coliform Count, TSC = Total Staphylococcal Count, TFC = \\
Total Fungal Count.
\end{tabular}

\subsection{DISCUSSION, CONCLUSION AND RECOMMENDATION}

\subsection{Discussion}

A hospital produces waste by giving their services to the patients. This waste can be produced directly in combination with the service (e.g., injection) or in the upstream (e.g., blood or urine cultures in the laboratory) or downstream (vaccine) process. One kind of typical diseases treated in hospitals is infectious diseases. By the services for known or unknown infectious patients, waste can be the source of an infectious agent.

This study revealed that there are two major types of wastes generated by health facilities in Aba metropolis which include municipal solid wastes which are non infectious wastes (such as food remains, bedding materials, papers, polyethylene bags etc) and special healthcare wastes which are infectious wastes (sharps, expired drugs, used x-rays film, swabs, nappies, blood bags etc). This finding aligned Rush et al. (2013) submission, where they stated that health waste comprises of the wastes originating from minor or scattered sources such as those produced in the process of health care undertaken in the home (dialysis, insulin injection etc.).

The microbial count of various waste samples within hospitals in Aba, Abia State showed that the viable count (TVC) maintained the highest number. However, the laboratory waste had the highest microbial counts, followed by the out-patient department waste and the least was the pharmaceutical waste. The pharmaceutical wastes were mostly paper and containers which maintained dry surfaces thereby discouraging the growth of most microorganisms except for those with low water activity. An earlier study by Ndimele et al. (2015) noted that high counts of bacterial load reflected the level of pollution in the environment, which is an indication of the amount of organic matter present. However, the high count observed in the study is of public health importance. These organisms can easily be carried into the hospital's environment by foot or other means which could increase the risk of infection. Also, they can be washed down by rain into the underground water of the hospitals leading to water contamination and spread of waterborne diseases. This observation disagreed with the results of Benediktsdóttir and, Kolstad (1984), which reported low microbial load in intramural hospital environment and agrees with another study of Apurva et al. (2010), who reported high bacterial load in the extramural environment. The waste dumpsite environment may influence the microbial counts at the reception area directly or 
International Journal of Health, Medicine and Nursing Practice ISSN 2710-1150 (Online)

Vol. 3, Issue No. 1, pp 17 - 23, 2021

$\underline{\text { www.carijournals.org }}$

indirectly, especially as the waste dumpsite is close to the hospitals and could have a direct effect on those attending or working in the hospitals. This could also lead to increase in disease condition or increase in hospital acquired infections.

The genera Escherichia, Klebsiella and Enterobacter (collectively called the coliform bacilli) and Proteus includes overt and opportunistic pathogens responsible for a wide range of infections (Guentzel, 2007). Bacillus cereus has been implicated in food-borne intoxication. Escherichia coli cause bacteraemia or urinary tract infections (Mahapatra and Mahapatra, 2005). Staphylococcus aureus and Pseudomonas aeruginosa cause diseases like mastitis, abortions and upper respiratory complications. Aside Escherichia species and some Bacillus sp., most microorganisms have been implicated as a causative agent of one waterborne disease or the other. For instance, Salmonella sp., Shigella sp., and proteus sp., are the causative agents of typhoid fever, dysentery and urinary tract infection respectively (Ogbulie, 2001). Aspergillus niger has been reported to cause lung diseases, aspergillosis and otomycosis. Similarly, most Aspergillus species are human and livestock pathogens associated with aspergillosis of the lungs and sometimes causing corneal, otomycotic and nasoorbital infections (Moyo et al., 2012). They produce significant quantity of aflatoxin (Klich, 2007). Candida albicans is reported to cause vaginitis and yeast mastitis (Moyo et al., 2012).

\subsection{Conclusions}

The high microbial load densities suggests that the hospital wastes in the environment pose a major health and environmental threat, which therefore calls for a proper regulatory system on disposal of hospital waste and there is an urgent need to raise awareness, education and management strategy on medical waste issues to ensure healthy and environmental safety.

\subsection{Recommendation}

The study recommends that, the government should ensure that there is a policy on hospital waste management in line with recommended international best practices, which should be monitored and enforced.

\section{REFERENCES}

Amusa, N. A., Ashayi, O. A., Aiyegbayo, A. A., Oladapo, M.O.O and Afalobi O.O. (2005). Microbiological and Nutritional quality of Hawked sorrel drink widely consumed and notable drink in Nigeria. Journal of Food, Agriculture and Environment, 3 (3 and 4): 4750 .

Cheesbrough, M. (2003). Water quality analysis. District Laboratory practice in Tropical countries (2). Cambridge University Press, United Kingdom. Pp. 146-157

Elendu C. Onwuchekwa, Uzochukwu G. Ekeleme, Oliver Onu-Osi, Okonudo, I. Diana (2019). Prevalence of typhoid fever in referral hospitals in Umuahia and Aba, Abia State, Nigeria. Advanced Journal of Microbiology Research ISSN 2241-9837 Vol. 13 (4), pp. 001-005. 
International Journal of Health, Medicine and Nursing Practice ISSN 2710-1150 (Online)

Vol. 3, Issue No. 1, pp 17 - 23, 2021

$\underline{\text { www.carijournals.org }}$

Gerhardt, P., Murray, R.G.E., Wood, W.A. and Krieg, N. R. (1994). Methods for General and Molecular Bacteriology. ASM Press, Washington DC, Pp.791.

Gibson, M. A, Gunmu, E. (2012) Rural to Urban Migration Is an Unforeseen Impact of Development Intervention in Ethiopia

Gupta S, Boojh R, Mishra A,Chandra H.(2009) Rules and management of biomedical waste at Vivekan and a Polyclinic. A case studies. Journal Waste Manag, 29(2):812819.I

Hormones, and Other Organic Waste Water Contaminants in U.S. Streams, 1999-2000: A National Reconnaissance. Environmental Science and Technology;36(6), 1202-11.

Klich, M. A. (2007). Aspergillus flavus: The major producer of aflatoxin. Mol. Plant Pathol., 8(6): 713-722.

Kolpin, D. Furlong, E. Meyer, M. Turman, E. Zaugg, S. Barber, L. (2002). Pharmaceuticals,

Moyo, B., Masika, P. J. and Muchenje, V. (2012). Antimicrobial activities of Moringa oleifera Lam leaf extracts. African Journal of Biotechnology, 11(11): 2797-2802.

Ndimele, E.C., Ekeleme, U.G., Ogodo, A.C. and Nwachukwu, N.C. (2015). Evaluation of the level of air microbial contamination in some teaching hospitals waste dump site in South-Eastern Nigeria. Nigerian Hospital Practice, 15(4): 31-38.

Ogbonna, D. (2011). Characteristics and waste management practices of Medical wastes in Health care institutions in Port Harcourt, Nigeria. Journal of Soil Science and environmental management. 2(5), 132-141.

Ogbulie, N. (2001). Water and sewage microbiology, In; Introductiory microbiology. 2nd Edition, Cancave Publishers, Owerri, Nigeria. pp.150-153.

Patil, G. V. and Pokhrel, K. (2005), Biomedical Solid Waste Management in an Indian Hospital: A Case Study, Waste Management, 25, 592-599.

Ekeleme, U. G., Ansari, R. A., Osaribie, N. A. and Rabiu, K. M. (2020). Microbial load of domestic water sources treated with Moringa oleifera and Jatropha curcas seed powder. South Asian Journal of Research in Microbiology, 7(4): 9-20

Ugbogu, O.C., Bigah, S. and Ogodo, A.C. (2015). Antimicrobial activities and microorganisms associated with herbal remedies sold in Ebonyi State, Nigeria. Global Journal of Microbiology Research, 3 (3): 141-149.

World Health Organization (2014) Safe management of wastes from health-care activities $2^{\text {nd }}$ Edition Edited by Chartier Y, Emmanuel J, Pieper U, Prüss A, Rushbrook P, Stringer R, etal, 2014. 